\title{
CONTRIBUTIONS TO THE BRYOPHYTE FLORA OF CENTRAL AND SOUTHERN ALBANIA
}

\author{
Beáta PAPP ${ }^{1}$, Peter Erzberger ${ }^{2} \&$ Jani MARKA ${ }^{3}$ \\ ${ }^{1}$ Botanical Department, Hungarian Natural History Museum \\ H-1431 Budapest,Pf. 137, Hungary; papp.beata@nhmus.bu \\ ${ }^{2}$ Belziger Str. 37, D-10823 Berlin, Germany \\ ${ }^{3}$ Department of Biology, Faculty of Natural Sciences, Tirana University \\ Blvd. Zogu I, Tirana, Albania
}

Papp, B., Erzberger, P. \& Marka, J. (2018): Contributions to the bryophyte flora of central and southern Albania. - Studia bot. hung. 49(2): 15-38.

\begin{abstract}
: 213 bryophyte taxa were recorded during a field trip leading to various sites of central and southern Albania. Nine species (Bryum ruderale, Fissidens adianthoides, F. crassipes, Grimmia fuscolutea, G. meridionalis, Orthotrichum patens, O. philibertii, Tortella fasciculata, T. inflexa) were collected for the first time in Albania. 31 species found have conservation interest; rare on the Balkans or even in Europe or/and candidates of the new European bryophyte red-list.
\end{abstract}

Key words: liverworts, mosses, new national records, species of conservation interest, the Balkans

\section{INTRODUCTION}

It has been mentioned in many publications how poorly known the bryophyte flora of Albania is (MARKa et al. 2018, SABovljević et al. 2008, SABovljević \& Natcheva 2006). Thus far 464 moss taxa (MARKa et al. 2018, MARKa 2014) and $c a .120$ liverworts (MARKa et al. 2018, SABovljević \& NatcheVa 2006) were reported. The total number of bryophyte taxa has recently been increased considerably (to $c a 585$ ), and is already comparable to the species diversity of other countries in the Balkan Peninsula (SABovLjević et al. 2011); this is due to a rise of interest and several collecting trips and publications during the last decade (e.g. Marka et al. 2018, Marka 2014, van Zanten 2013, Papp et al. 2010a). The most investigated areas have been in the Albanian Alps and Korça region, in northern and southeastern Albania, respectively. However, still much of Albanian territory is not even superficially investigated for bryophytes. In this paper data are presented mainly from central and southern Albania, in the districts of Librazhd, Skrapar, Përmet, Gjirokastër, Sarandë and Vlorë. 


\section{MATERIAL AND METHODS}

\section{Description of the investigated area}

The geographical area investigated in this paper is very broad and continuous from the central to the southernmost part of Albania, which makes it inappropriate to give very detailed descriptions for each of the areas. Albania is divided in 4 major geographical areas, which are subdivided in 47 smaller units. From four major geographical areas two - the Central Mountainous Region and the Southern Mountainous Region - were investigated for bryophytes in various sites. However, herein geographical data will be limited for the most representative smaller units that were investigated. The information on this section is mainly based on the monograph of KABO (1991).

\section{Polis Mountains}

The Polis Mts are located in the Central Mountainous Region of Albania, specifically in the mountain ranges between Shkumbini valley and Devolli valley, starting from the Shkumbini gorges in the north up to Sopot and Shpellë in the south. The Polis Mts start from $200 \mathrm{~m}$ a. s. 1 . up to $1800 \mathrm{~m}$ a. s. 1., with prevailing elevation above $1000 \mathrm{~m}$ a. s. 1 . It is mainly composed of calcareous and magmatic rocks. Due to karstic development it has sparse vegetation. However, the vegetation is denser in the surroundings of the carbonate plates, where the humidity is also higher, and it is mainly composed of beech forests, especially in the slopes.

\section{Osumi valley}

Osumi valley is one of the longest valleys in Albania; in this study only the middle part is considered, which is part of the Southern Mountainous Region. Osumi valley has layers of carbonates and flysch/schist, and it is characterized by erosion and terraces as well. Its vegetation is composed of types of the Mediterranean vegetation belt, with shrubs like Quercus ilex, Phillyrea spp., Pistacia lentiscus, Arbutus unedo, Erica arborea, etc. However, the valley is under the impact of anthropogenic activities, agriculture, and tourism.

\section{Lengarica valley}

Lengarica valley, southeast of Osumi valley, which is a part of the Southern Mountainous Region, breaks through between two mountain areas, Dangëllia and Leskoviku. It goes through various lithological substrates, mainly carbonates and terrigenous rocks. Lengarica is also known for its thermal springs. Its 
vegetation is again composed of types of the Mediterranean vegetation belt, as mentioned for Osumi valley.

\section{Zagoria valley}

Zagoria valley is situated between Dhëmbeli Mts eastward and Lunxhëri Mts westward, in the Southern Mountainous Region. It is composed of flysch and quaternary sediments. The bottom of the valley is about $700 \mathrm{~m}$ a. s. 1 . at the upper part and about $200 \mathrm{~m}$ a. s. 1. at its outlet. The erosive processes are powerful especially in its right side slope, and terraces are developed as well. The valley is penetrated by numerous shallow and dry streams. It has a cold climate in the winter, and with enduring snow due to cold winds. The vegetation of the valley is relatively sparse due to long anthropogenic pressure. It is composed of vegetation types of the oak belt, with various Quercus species, Carpinus orientalis, Coryllus avellana, Juniperus, etc.

\section{The gorge of Suba}

The gorge of Suha is situated between the Lunxhëri Mts and the Bureto Mts, in the Southern Mountainous Region. The average altitude is about $500 \mathrm{~m}$ a.s.l., it is dominated by calcareous substrates and the vegetation the same as mentioned for Zagoria valley.

\section{Blue Eye}

Blue Eye (Syri i Kaltër) is located in the Delvina depression at the bottom of the Mali i Gjerë Mts, and its karstic spring is the main source of Bistrica River. The geological substrates are of the calcareous type. Blue Eye is a protected area in Albania in the category of Natural Monument (AKZM 2018). It is surrounded by a dense vegetation of evergreen maquis with shrubs and trees like Pistacia lentiscus, Arbutus unedo, Laurus nobilis, Juniperus oxycedrus; there are also old Platanus orientalis trees around the spring and along water courses.

\section{Mursia and Vrina plane and their surrounding hills}

Mursia and Vrina were formerly marshlands, as a consequence of floods from the Pavlla River. After the regulation of the Pavlla River and construction of the artificial lake of Mursia, these fields became highly productive agricultural fields. Mursia plane is surrounded by low hills $(50-100 \mathrm{~m})$, which are composed of clays and calcareous substrates, and covered by dry grasslands and phryganes. 


\section{Palermo bay}

Palermo bay is located in the upper part of the Ionic Riviera with a typical Mediterranean climate and vegetation (maquis and phryganes). Geologically it is a calcareous area.

\section{Methods}

Our collecting trip was made in October 2010. Various habitat types, such as wetlands, streams and riverbanks, calcareous and siliceous rock formations, grasslands, shrubberies, forests were investigated, and bryophytes collected from different substrates (soil, exposed and shaded rocks, tree bark, and decaying wood). The collecting sites can be seen in Figure 1.

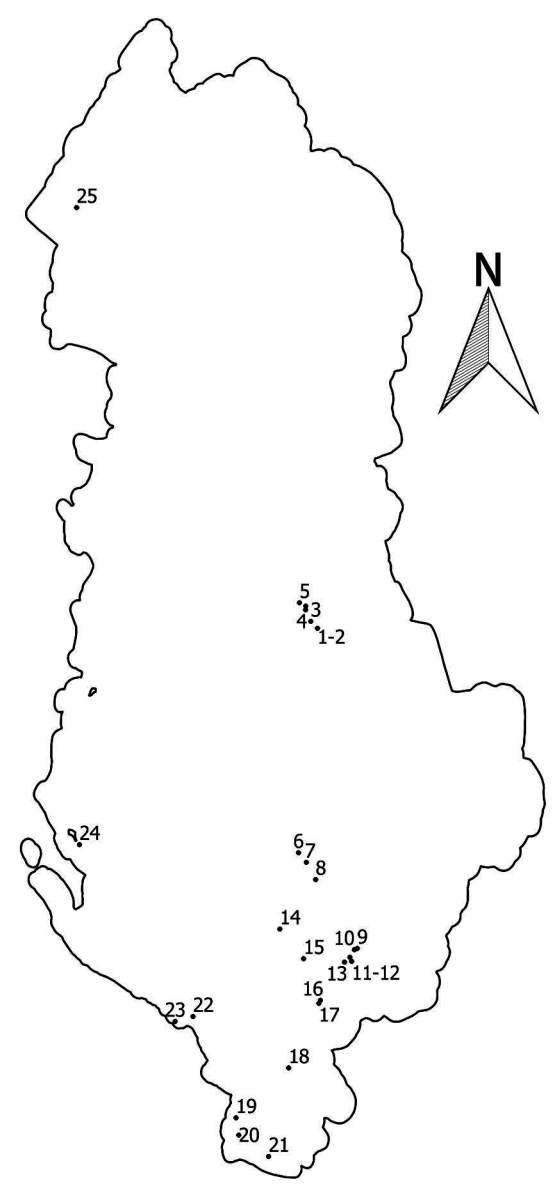

Fig. 1. Location of collecting sites 
The specimens are stored in the Herbarium of the Hungarian Natural History Museum, Budapest (BP), in the Herbarium of the Botanic Garden and Botanical Museum, Berlin-Dahlem (B), and in the JM collection at the Department of Biology (University of Tirana).

Nomenclature of bryophytes follows Hodget ts (2015), but for Bartramia aprica, Müller (2014), for Didymodon tophaceus subsp. sicculus, KuČERA et al. (2018), for Fissidens bambergeri, AHRENs (2000), and for Tortula muralis var. aestiva, Ahrens \& NeBEL (2000) were followed.

If species distributions are indicated for SE Europe, the following abbreviations are used: ALB - Albania, BG - Bulgaria, BIH - Bosnia and Herzegovina, GR - Greece, HR - Croatia, MK - Macedonia, MNE - Montenegro, RO - Romania, SLO - Slovenia, SRB - Serbia, TR - European part of Turkey. Abbreviations of red list categories are as follows: $\mathrm{CR}$ - critically endangered, EN - endangered, VU - vulnerable, NT - near threatened, DD - data deficient, $\mathrm{DD}^{*}$ - data deficient, newly recorded. Country distributions, national red list categories in SE Europe and indication of candidates for the new European red-list are taken from HoDGETTs (2015), with updates where relevant.

\section{Site and collecting details}

1) Albania, District of Librazhd (Rrethi i Librazhdit), Polis Mts, above village Polis, on the ridge between the valley of brook "Sut Kukit" and river Shkumbin; in bushland, N $41.154500^{\circ}, \mathrm{E}$ $20.252472^{\circ}, 575 \mathrm{~m}, 12.10 .2010$.

2) Albania, District of Librazhd (Rrethi i Librazhdit), Polis Mts, above Vilan village, N $41.095694^{\circ}$, E $20.293333^{\circ}, 1385 \mathrm{~m}, 12.10 .2010$.

3) Albania, District of Librazhd (Rrethi i Librazhdit), Polis Mts, at Gurrëshpat village, in a Fagetum $\mathrm{N} 41.114083^{\circ}, \mathrm{E} 20.269805^{\circ}, 1075 \mathrm{~m}, 12.10 .2010$.

4) Albania, District of Librazhd (Rrethi i Librazhdit), Polis Mts, in village Polis; on limestone out-

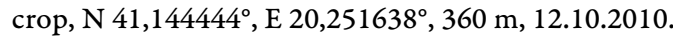

5) Albania, District of Librazhd (Rrethi i Librazhdit), next to the bridge over river Shkumbin, between villages Goshtimë and Mirakë, N 41.163361 ${ }^{\circ}$ E 20.230277, 190 m, 12.10.2010.

6) Albania, District of Skrapar (Rrethi i Skraparit), at river Osum next to Çorovode, N $40.500055^{\circ}$, E $20.227055^{\circ}, 195 \mathrm{~m}, 13.10 .2010$.

7) Albania, District of Skrapar (Rrethi i Skraparit), above the gorge of river Osum next to Dhorës village; in open bushland, $\mathrm{N} 40.474361^{\circ}$, E 20.254277 $, 400 \mathrm{~m}, 13.10 .2010$.

8) Albania, District of Skrapar (Rrethi i Skraparit), in the gorge of river Osum near village Lapan (Zabërzan), N 40.428388 ${ }^{\circ}$ E $20.287111^{\circ}, 370 \mathrm{~m}, 13.10 .2010$.

9) Albania, District of Përmet (Rrethi i Përmetit), Lengarica valley, above the gorge of stream (at hot springs Linxha uji thermale); in bushland, N 40.244388, E 20.432555 , $350 \mathrm{~m}, 14.10 .2010$.

10) Albania, District of Përmet (Rrethi i Përmetit), Lengarica valley, at the brook përroi i Benjës at the junction towards village Benjë, N 40.241055 , E 20.422472 $, 375 \mathrm{~m}, 14.10 .2010$.

11) Albania, District of Përmet (Rrethi i Përmetit), Lengarica valley, Mali i Bardhë, around the restaurant along the way from Petran to hot springs Linxha Uji thermale; at the spring and on the rock wall at the roadside, $\mathrm{N} 40.220555^{\circ}, \mathrm{E} 20.406861^{\circ}, 320 \mathrm{~m}, 14.10 .2010$. 
12) Albania, District of Përmet (Rrethi i Përmetit), Lengarica valley, at the limestone cliff next to village Petran, at the confluence of river Vjosë and Lengaricë stream, N $40.209722^{\circ}, \mathrm{E}$ $20.412916^{\circ}, 300 \mathrm{~m}, 14.10 .2010$.

13) Albania, District of Përmet (Rrethi i Përmetit), at the river Vjosë, below village Badelonjë, N $40.207694^{\circ}, \mathrm{E} 20.387833^{\circ}, 260 \mathrm{~m}, 14.10 .2010$.

14) Albania, District of Përmet (Rrethi i Përmetit), Uji i Ftohtë in Gryka e Këlcyrës; around karstic springs, $\mathrm{N} 40.296277^{\circ}$, E $20.161638^{\circ}, 175 \mathrm{~m}, 14.10 .2010$.

15) Albania, District of Gjirokastër (Rrethi i Gjirokastrës), Zagoria valley, from village Hoshtevë down to Zagori river, $\mathrm{N} 40.216888^{\circ}$, E $20.244888^{\circ}$ and $\mathrm{N} 40.214277^{\circ}$, E $20.236583^{\circ}, 735-545$ $\mathrm{m}, 15.10 .2010$.

16) Albania, District of Gjirokastër (Rrethi i Gjirokastrës), Gryka e Suhës near village Selcë; limestone and conglomerate rocks, $\mathrm{N} 40.105444^{\circ}, \mathrm{E} 20.303638^{\circ}, 470 \mathrm{~m}, 16.10 .2010$.

17) Albania, District of Gjirokastër (Rrethi i Gjirokastrës), Gryka e Suhës near village Selcë; downstream on Suhë stream, N $40.097277^{\circ}$, E 20.298000, 395 m, 16.10.2010.

18) Albania, District of Sarandë (Rrethi i Sarandës), around the karstic spring Syri i Kaltër, N $39.923805^{\circ}, \mathrm{E} 20.192472^{\circ}, 170 \mathrm{~m}, 16.10 .2010$.

19) Albania, District of Sarandë (Rrethi i Sarandës), Mt Maja e Dhema, between village Ksamil and Pasqyrë; on limestone rocks in phrygana dominated by Euphorbia dendroides, N $39.789500^{\circ}$, E $20.008416^{\circ}, 65 \mathrm{~m}, 17.10 .2010$.

20) Albania, District of Sarandë (Rrethi i Sarandës), along canal Kanal i Butrintit N of village Vrinë; in saline habitat, $\mathrm{N} 39.742833^{\circ}$, E $20.018000^{\circ}, 5 \mathrm{~m}, 17.10 .2010$.

21) Albania, District of Sarandë (Rrethi i Sarandës), on the slope of Mt. "Xtoi" $271.5 \mathrm{~m}$, between vil-

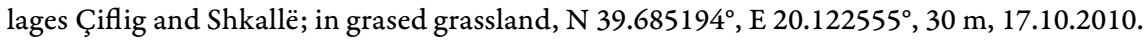

22) Albania, District of Vlorë (Rrethi i Vlorës), around spring Burimi Borshit (Restaurant Ujëvara), in village Borsh, $\mathrm{N} 40.061833^{\circ}$, E 19.858138 $100 \mathrm{~m}, 18.10 .2010$.

23) Albania, District of Vlorë (Rrethi i Vlorës), on Palermo peninsula near the military station; in rocky grassland on limestone, $\mathrm{N} 40.048694^{\circ}$, E $19.795361^{\circ}, 90 \mathrm{~m}, 18.10 .2010$.

24) Albania, District of Vlorë (Rrethi i Vlorës), at lake Liqeni i Nartës near village Panaja; in saline grassland, $\mathrm{N} 40.521472^{\circ}, \mathrm{E} 19.460666^{\circ}, 3 \mathrm{~m}, 18.10 .2010$.

25) Albania, Malësi e Madhe District (Rrethi i Malësisë së Madhe), in the S part of town Koplik; small pond at the roadside, $\mathrm{N} 42.198083^{\circ}, \mathrm{E} 19.450888^{\circ}, 50 \mathrm{~m}, 19.10 .2010$.

\section{RESULTS AND DISCUSSION}

213 bryophyte taxa ( 26 liverworts and 187 mosses) were recorded during our field trip. The complete list of the species can be found in the Appendix. Nine species are reported for the first time from Albania. 31 species have conservation interest; rare on the Balkans or even in Europe or/and candidates of the new European bryophyte red-list.

\section{Species new to the Albanian bryophyte flora}

Bryum ruderale Crundw. \& Nyholm - This is a subatlantic species (DÜLL 1985). In SE Europe it is known only from BG (DD*), HR, GR, RO (CR), SRB, and TR. It is widely distributed in Europe, but under-recorded due to its small size. It was collected in a saline grassland in SW Albania. 
Fissidens adianthoides Hedw. - This subboreal species (DÜLL 1984) is widely distributed in Europe, it is known in all SE European countries except ALB. In MNE it is $\mathrm{DD}^{*}$, because it has been reported recently from the Durmitor Mts (PAPP \& ERZBerger 2010). In Albania it was collected in a wet site along a rivulet in the Polis Mts above $1000 \mathrm{~m}$ a. s. 1 .

Fissidens crassipes Wilson ex Bruch \& Schimp. - This subatlantic-sub-Mediterranean aquatic species (DüLL 1984) is known from almost all SE European countries except ALB, MK, and TR. It is redlisted in BG (VU) and RO (EN). In Northern and Central Europe it is also red-listed in many countries like Norway (CR), Sweden, Austria, Poland, Slovakia (EN), Czech Republic (DD), Germany (not evaluated due to the lack of knowledge of this taxon), and Latvia (EN). It seems that this species can tolerate wide trophic range of the water; e.g. it is a characteristic species of mesosaprobic sections of the Danube (PAPP \& RAJCZY 1995, PAPP et al. 2006). It was found on limestone rock at a stream in Southern Albania.

Grimmia fuscolutea Hook. - This species is a candidate for the new European Bryophyte Red List. In SE Europe it is known only in BG (NT), MK, MNE, and $\mathrm{RO}(\mathrm{CR})$. It has a scattered distribution in Europe. Where it occurs it is often redlisted, e.g. Finland (EN), Sweden (VU), Germany (not evaluated due to the lack of knowledge of this taxon), Slovakia (DD), and Switzerland (VU). It was collected from conglomerate flysch sediment in the Polis Mts in Central Albania.

Grimmia meridionalis (Müll. Hall.) E. Maier - This species is also a candidate for the new European Bryophyte Red List. In SE Europe it is reported only from BG and GR. In Europe it is known from the Western Mediterranean countries, Cyprus and Germany (DD). It was also found in conglomerate flysch sediment in the Polis Mts in Central Albania.

Orthotrichum patens Bruch ex Brid. - This subatlantic species (DüLL 1985) is a candidate for the new European Bryophyte Red List. It is known from almost all SE European countries except ALB, TR, and doubtful in GR. It is red-listed in RO (VU) and BG (NT). It is distributed all over Europe, but red-listed in many European countries. In Hungary it is vulnerable (VU) according to the national bryophyte red-list of 2010 (PAPP et al. 2010b), but since then several new records have been discovered, and it seems it is expanding (PAPP \& SzURDoKi 2017, 2018). It was found on tree bark in Zagoria valley in Southern Albania.

Orthotrichum philibertii Venturi - This Atlantic-Mediterranean species (DüLL 1985) is a candidate for the new European Bryophyte Red List. In SE Europe it is known only from GR, RO (CR), and SRB (EN). In Europe it is also reported from Norway, Balearic Islands, Corsica, Cyprus, France, Italy, Portugal (DD), Sardinia, Sicily (NT), and Spain (VU). It was found on Sorbus bark in Zagoria valley in Southern Albania. 
Tortella fasciculata (Culm.) Culm. - According to KöcKINGER \& HEDENÄs (2017) Tortella bambergeri (Schimp.) Broth. consists of two independent species: Tortella fasciculata (Culm.) Culm. and T. pseudofragilis (Thér.) Köckinger \& Hedenäs. T. fasciculata is a thermophilous moss and can be characterized as a suboceanic-sub-Mediterranean floristic element in Europe. It was collected from limestone rocks in two sites in the Polis Mts in Central Albania.

Tortella inflexa (Bruch) Broth. - This Atlantic-Mediterranean species (DÜLL 1984) is known from almost all SE European countries except ALB, RO, and TR. It is red-listed in SLO (VU) and BG (DD), because it has recently been reported from the Strandzha Mts (PAPP et al. 2011). It is widely distributed in the Western Mediterranean, it is also known in Great Britain, Belgium, Germany (extremely rare), and the Netherlands (susceptible). It was found on limestone rock along a river in Southern Albania.

\section{Species of conservation interest}

\section{Liverworts}

Clevea spathysii (Lindenb.) Müll. Frib. - This southern Atlantic-Mediterranean species (DÜLL 1984) is a candidate for the new European Bryophyte Red List. In SE Europe it is known only from GR, Crete, and ALB (DD). In Europe it is also reported from the Balearic Islands, Canary islands, Corsica, France, Italy (CR), Portugal, Sicily, and Spain.

Oxymitra incrassata (Brot.) Sérgio \& Sim-Sim - This submediterranean species (DüLL 1984) is a candidate for the new European Bryophyte Red List. In SE Europe it is known only from ALB (DD), BG, GR, HR, MNE, RO (VU), and $S R B$. It is red-listed in many other European countries, where it occurs, e.g. in Hungary (NT), Austria (CR), Czech Republic (EN), Poland (EN), Slovakia (CR), Switzerland (VU), and Italy (CR).

Radula lindenbergiana Gottsche ex C.Hartm. - It is a submediterranean, montane species (DÜLL 1984). It is known from almost all SE European countries except MK, but it is not frequent in the Balkans. It is red-listed in BG (VU). In Europe it is also red-listed in Hungary (DD), Italy (NT), Czech Republic (VU), Germany (DD), and Finland (VU).

\section{Mosses}

Bryum canariense Brid. - This Atlantic, Mediterranean species (DüLL 1985 ) is data-deficient (DD) in Albania as only very old records exist. It is known from almost all SE European countries except RO. It has recently been reported from SRB (PAPP et al. 2014a). It is red-listed in BG (VU) and in SLO (DD). 
Bryum klinggraeffii Schimp. - This subatlantic species (DüLL 1985) has recently been reported as new to the Albanian bryophyte flora in MARKA et al. (2018) from Valbona valley. In SE Europe it is known only from BG (DD*), GR, MK, RO (EN), and SLO (DD). This tiny moss is surely over-looked and undercollected in the Balkans.

Cryphaea heteromalla (Hedw.) D. Mohr - This is a subatlantic, Mediterranean species (DüLL 1985). It has recently been reported as new to the Albanian bryophyte flora in MARKA et al. (2013) on the basis of four specimens collected in different parts of Albania. This (loc. 18.) is the southernmost locality in the country. In SE Europe it is also known from HR, GR, MNE, RO (CR), SLO (DD), and TR.

Didymodon tophaceus subsp. sicculus (M. J. Cano, Ros, García-Zam. \& J. Guerra) Kučera - This species has recently been reported as new to the Albanian bryophyte flora in MARKA et al. (2013) on the basis of the specimen found at loc. 20. In SE Europe it is also known from BG (DD*), GR, MNE, SRB, SLO (DD*), and TR.

Drepanocladus polygamus (Schimp.) Hedenäs - This boreal wetland species (DÜLL 1985) is a candidate for the new European Bryophyte Red List. It is DD* in Albania as it has recently been reported for the first time from the country (PAPP et al. 2010a). It is also known from many SE European countries, but it is often redlisted: BG (VU), MK, MNE (VU), RO (VU), SRB (VU), and SLO (VU).

Entostbodon mublenbergii (Turner) Fife - This sub-Mediterranean, subatlantic, montane species (DüLL 1985) is a candidate for the new European Bryophyte Red List. It is DD in Albania as only very old records exist. It is known from all SE European countries except TR. Red-listed in RO (VU).

Entostbodon pulchellus (H. Philib.) Brugués - This sub-Mediterranean, subatlantic, montane species (DÜLL 1985) is also a candidate for the new European Bryophyte Red List. It is DD* in Albania as it was recently reported by ERzBERGER (2007). It is known from all SE European countries except BG, RO, and TR. It is also red-listed in SLO (DD*).

Ephemerum recurvifolium (Dicks.) Boulay - This sub-Mediterranean species (DÜLL 1984) is also a candidate for the new European Bryophyte Red List. It has recently been reported as new to the Albanian bryophyte flora in MARKA et al. (2013) on the basis of the specimen found at loc. 20. In SE Europe it is known from a few countries and often red-listed in high categories in BG (CR), GR (Crete), HR, MNE (VU), and RO (CR).

Fabronia pusilla Raddi - This sub-Mediterranean species (DÜLL 1985) is also a candidate for the new European Bryophyte Red List. It is DD* in Albania as it has recently been reported for the first time from the country (PAPP et al. $2010 a$ ). It is known from almost all SE European countries except BIH, SRB, and $\mathrm{TR}$, but it is frequently red-listed, e.g. $\mathrm{BG}(\mathrm{VU}), \mathrm{MNE}(\mathrm{DD}), \mathrm{RO}(\mathrm{CR})$, and SLO 
(DD). However, in Albania it seems to be quite common and abundant even in city centres (MARKA \& ZALOSHNJA 2017).

Fissidens curvatus Hornsch. - This Atlantic, Mediterranean species (DÜLL 1984 ) is included in the Red Data Book of European Bryophytes (ECCB 1995) and a candidate for the new European Bryophyte Red List. It is DD* in Albania as it has recently been reported for the first time from the country (PAPP et al. 2010 a). It is known only from BG (DD*), HR, GR, and MNE (DD).

Grimmia decipiens (Schultz) Lindb. - This subatlantic, montane species (DüLL 1984) is DD* in Albania as it has recently been reported for the first time from the country (PAPP et al. 2010a). It is known from almost all SE European countries except BIH and SLO, but it is not frequent. It is red-listed in BG (VU) and $\mathrm{RO}(\mathrm{EN})$.

Imbribryum mildeanum (Jur.) J. R. Spence - This subatlantic species (DÜLL 1985 ) is a candidate for the new European Bryophyte Red List. It has recently been reported as new to the Albanian bryophyte flora in MARKA et al. (2018). In SE Europe it is known from BIH, BG (EN), HR, GR, RO (EN), SRB, and SLO.

Isothecium myosuroides Brid. - This is a subatlantic species (DÜLL 1985) with sub-Mediterranean character. It is $\mathrm{DD}^{*}$ in Albania as it has recently been reported for the first time from the country (PAPP et al. 2010a). It is known from almost all SE European countries except MK. It is red-listed in BG (CR).

Orthotrichum alpestre Bruch \& Schimp. - This subarctic, subalpine species (DüLL 1985) is DD* in Albania as it has recently been reported for the first time from the country (PAPP et al. 2010a). In SE Europe it is known only from BIH, $\mathrm{GR}, \mathrm{MK}, \mathrm{MNE}$, and RO (VU).

Orthotrichum shawii Wilson - This is a candidate for the new European Bryophyte Red List. It is DD* in Albania, but it seems that it is not rare in the country evidenced by historical and recent collections (KÁRPÁTI \& VAJDA 1961, PAPP et al. 2010a, MARKA 2014). In SE Europe it is also known from GR. It has recently been reported from MK (PAPP et al. 2016).

Philonotis caespitosa Jur. - This boreal species (DÜLL 1985) is DD* in Albania as it has recently been reported for the first time from the country (PAPP et al. 2010a). It is also known from all SE European countries, but often red-listed, e.g. BG (VU), MNE (DD), SRB (DD), and SLO (VU).

Philonotis capillaris Lindb. - This subatlantic species (DüLL 1985) has recently been reported as new to the Albanian bryophyte flora by MARKA et al. (2013) based on the specimen found at loc. 1. It is known from almost all SE European countries except $\mathrm{HR}$ and TR, but often red-listed, e.g. BG (VU), MNE (DD), RO (EN), SRB (DD), and SLO (NT).

Philonotis marchica (Hedw.) Brid. - This sub-Mediterranean species (DÜLL 1985 ) is a candidate for the new European Bryophyte Red List. It is known from 
almost all SE European countries except HR, but often red-listed, e.g. ALB (DD), $\mathrm{BG}(\mathrm{EN}), \mathrm{RO}(\mathrm{NT})$, and SLO (NT).

Pseudoleskeella rupestris (Berggr.) Hedenäs \& L. Söderstr. - This species is also a candidate for the new European Bryophyte Red List. It has recently been reported from many SE European countries, like ALB (PAPP et al. 2010a), HR (Alegro et al. 2015), GR (PAPP \& TsAKIRI 2017), MK (PAPP et al. 2016), MNE (Dragićević et al. 2008), and SRB (PAPP et al. 2014b).

Rhynchostegiella teneriffae (Mont.) Dirkse \& Bouman - This Atlantic, subMediterranean, montane species (DüLl 1985) is included in the Red Data Book of European Bryophytes (ECCB 1995) and a candidate for the new European Bryophyte Red List. It has recently been reported as new to the Albanian bryophyte flora in MARKA et al. (2013) on the basis of the specimen found at loc. 18. It is known from almost all SE European countries except $\mathrm{MK}$ and TR, but often red-listed, e.g. BG (DD*), RO (CR), and SLO (VU).

Schistidium atrofuscum (Schimp.) Limpr. - It is DD* in Albania since it has recently been reported for the first time from the country (PAPP et al. 2010a). It is known from almost all SE European countries except TR. It is NT in BG and RO.

Schistidium flaccidum (De Not.) Ochyra - It is DD* in Albania as it has recently been reported for the first time from the country (PAPP et al. 2010a). It is known from almost all SE European countries except HR, MNE, and TR. It is red-listed in BG (NT) and RO (CR).

Schistidium belveticum (Schkuhr) Deguchi - This species is a candidate for the new European Bryophyte Red List. It is DD* in Albania since it has recently been reported for the first time from the country (PAPP et al. 2010a). It is known from almost all SE European countries except SLO. It is also DD* in BG; in RO it cannot be evaluated (NE) due to the lack of knowledge. It seems that this is a frequent species in the Balkans on exposed limestone rocks.

Schistidium papillosum Culm. - This species is a candidate for the new European Bryophyte Red List. It is DD* in Albania as it has recently been reported for the first time from the country (MARKA \& XHULAJ 2011). In SE Europe it is also known from BG (DD*), GR, MK, MNE (DD*), RO, SRB, and doubtful in SLO.

Scorpiurium sendtneri (Schimp.) M. Fleisch. - This sub-Mediterranean, subatlantic species (DÜLL 1985) is a candidate for the new European Bryophyte Red List. It has recently been reported as new to the Albanian bryophyte flora in MARKA et al. (2013) based on two specimens; one of them is the record from loc. 18. In SE Europe it is known only from ALB, HR, GR, MNE, and SLO (EN).

Seligeria pusilla (Hedw.) Bruch \& Schimp. - This species of the temperate zone of Europe (DüLL 1984) has recently been reported as new to the Albanian bryophyte flora in MARKA et al. (2018) from Valbona valley. It is known from 
almost all SE European countries except TR. It is red-listed in BG (VU) and SRB (VU).

Syntrichia laevipila Brid. - This Atlantic, submediterranean species (DÜLL 1984 ) is DD* in Albania, but it has already many records (ColACINo \& MARKA 2009; PAPP et al. 2010b; VAn ZANTEN 2013; MARKA 2014; MARKA \& ZaloshNJA 2017), hence its DD* status could be revised. It is known from almost all SE European countries except BIH and TR. It is red-listed in BG (VU), RO (CR), and SLO (VU).

Syntrichia montana Nees var. calva (Durieu \& Sagot ex Bruch \& Schimp.) J. J. Amann - This taxon occurring in the temperate zone of Europe (DÜLL 1984) is known only from ALB, GR, MK, and SRB in SE Europe.

\section{CONCLUSIONS}

In spite of the recent improvement in the exploration of the bryophyte flora of Albania still each field trip can add several new taxa to the bryoflora of the country. The present paper with new national records of mainly (sub)Atlantic(sub)Mediterranean species can contribute to the checklist of bryophytes of Albania. Besides this, several valuable records of species of European conservation interest or rare, threatened taxa on the Balkans are also reported. Most of them are also characterised by (sub)Atlantic-(sub)Mediterranean distribution.

Acknowledgements - We are indebted to the late Wiebke Schröder and Ludwig Meinunger (Ludwigsstadt-Ebersdorf), the late Eva Maier (Geneva), Ricardo Garilleti (Valencia), Cecilia Sérgio (Lisboa), Halina Bednarek-Ochyra (Krakow) for their help in confirmation, identification, or revision of some problematic specimens. We say thanks to Zoltán Barina (Budapest) for the preparation of the map.

Összefoglaló: Számos korábbi publikáció következtetései között szerepel, Albánia mohaflórája kevéssé feltárt. Az utóbbi évek intenzív mohászati kutatásainak, expedícióknak köszönhetően az országból kimutatott mohataxonok száma mára már mintegy 585, mely szám már összevethető a Balkán-félsziget más országaiban ismert mohadiverzitással. Albánia északi és délkeleti részének (Albán Alpok, Korça regió) mohaflórája jelenleg jobban feltárt, sok más vidékről azonban nagyon kevés adat áll rendelkezésre. Jelen cikkben egy 2010-es expedíció során Közép- és Dél-Albánia vidékein, Librazhd, Skrapar, Përmet, Gjirokastër, Sarandë és Vlorë régiókban gyűjtött anyag feldolgozásából született eredményeket közöljük.

Összesen 213 mohataxont találtunk, amelyek közül 9 fajt (Bryum ruderale, Fissidens adianthoides, F. crassipes, Grimmia fuscolutea, G. meridionalis, Orthotrichum patens, O. philibertii, Tortella fasciculata, T. inflexa) elöször közlünk Albánia területéröl. 31 faj pedig ritka, veszélyeztetett a Balkánon vagy egész Európában és a készülő új Európai Moha Vörös Lista potenciális tagja. 


\section{REFERENCES}

Ahrens M. (2000): Fissidentaceae, Spaltzahnmoose. - In: Nebel M. \& Philippi G. (eds): Die Moose Baden-Württembergs, Band 1. Ulmer, Stuttgart, pp. 230-369.

Ahrens M. \& Nebel M. (2000): Pottiaceae, Pottmoose. - In: Nebel M. \& Philippi G. (eds): Die Moose Baden-Württembergs, Band 1. Ulmer, Stuttgart, pp. 230-369.

AKZM (2018): Agjencia Kombëtare e Zonave të Mbrojtura-National Agency of Protected Areas: http://akzm.gov.al/us/protected-areas/natural-monument/item/156-blue-eye (accessed on 28 October 2018).

Alegro A., Šegota V. \& PAPp B. (2015): A contribution to the bryophyte flora of Croatia IV. Žumberačka gora Mts. - Studia bot. hung. 46(1): 5-24. http://dx.doi.org/10.17110/StudBot.2015.46.1.5

COLACINO C. \& MARKA J. (2009): Bryophytes of the Karavasta Lagoon area, with new reports for Albania. - Phytol. Balcanica 15: 39-42.

Dragićević S., Veljić M. \& MARIN P. (2008): New records to the moss flora of Montenegro. Cryptog. Bryol. 29(4): 397-400.

DüLL R. (1984): Distribution of the European and Macaronesian mosses (Bryophytina) I. - Bryol. Beiträge 4: 1-109.

DüLL R. (1985): Distribution of the European and Macaronesian mosses (Bryophytina) II. - Bryol. Beiträge 5: 110-232.

Erzberger P. (2007): Entosthodon pulchellus (H. Philib.) Brugués, Grimmia anomala Hampe ex Schimp. In: BlockeEl T. (ed.): New national and regional bryophyte records, 16. - J. Bryol. 29(3): 199-200.

HodgetTs N. G. (2015): Checklist and country status of European bryophytes - towards a new red list for Europe. - Irish Wildlife Manuals, No. 84. National Parks and Wildlife Service, Department of Arts, Heritage and the Gaeltacht, Ireland, $125 \mathrm{pp}$.

Каво M. (1991): Gjeografia fizike e Shqipërisë(Vëllimi II). - Akademia e Shkencave, Qendra e Studimeve Gjeografike, Tiranë, $592 \mathrm{pp}$.

KÁRPÁti I. \& VAJDA L. (1961): Beiträge zur Moosflora Albaniens. - Fragmenta Botanica 1: 3-16.

Köckinger H. \& HedenÄs L. (2017): A farewell to Tortella bambergeri (Pottiaceae) as understood over the last decades. - J. Bryol. 39(3): 213-225. https://doi.org/10.1080/03736687.2017.1307313

Kučera J., Blockeel T. L., Erzberger P., Papp B., Soldán Z., Vellak K., Werner O. \& Ros R. M. (2018): Didymodon tophaceus complex (Pottiaceae, Bryophyta) revisited: new data support the subspecific rank of currently recognized species - Cryptog. Bryol. 39(2): 241-257. https://doi.org/10.7872/cryb/v39.iss2.2018.241

MARKA J. (2014): Briofite të Shqipërisë: studim floristik dhe ekologjik. - Manuscript, doctoral thesis, University of Tirana.

MARKA J. \& ZAloshnja I. (2017): Epiphytic mosses in the centre of Tirana city (Albania). - Studia bot. hung. 48(1): 51-65. https://doi.org/10.17110/StudBot.2017.48.1.51

Marka J. \& Xhulaj M. (2011): Mosses from Lura region (Albania). - Int. J. Ecosyst. Ecol. Sci. 1: $27-30$.

Marka J., Erzberger P. \& PApp B. (2013): New and interesting moss records from Albania. - J. Bryol. 35(2): 152-155. https://doi.org/10.1179/1743282013Y.0000000053

Marka J., Blockeel T. L., Long D. G. \& Papp B. (2018): Bryophytes new to Albania from the British Bryological Society field meeting in 2014. - J. Bryol. 40(2): 163-172.

https://doi.org/10.1080/03736687.2018.1428072 
MÜLLER F. (2014): Bartramia aprica - the correct name for the Mediterranean and western North American species historically recognized as "Bartramia stricta". - Herzogia 27: 211-214. https://doi.org/10.13158/heia.27.1.2014.211

PAPP B. \& RAJCZY M. (1995): Changes of bryophyte vegetation and habitat conditions along a section of the river Danube in Hungary. - Cryptog. Helv. 18: 95-105.

Papp B., Ganeva A. \& Natcheva R. (2006): Bryophyte vegetation of Iskur River and its main tributaries. - Phytol. Balcanica 12(2): 181-189.

PAPP B. \& ERZBerger P. (2010): Contribution to the bryophyte flora of Durmitor National Park, Montenegro. - Nova Hedwigia 138: 145-161.

Papp B., Erzberger P. \& MArka J. (2010a): Contribution to the bryophyte flora of Eastern Albania (Korça and Kolonja Districts) - Studia bot. hung. 41: 61-88.

Papp B., Szurdoki E. \& Sabovljević M. (2014a): Bryum canariense (Brid.) Bruch. \& Schimp. [Serbia]. - In Ellis L. T. (ed.): New national and regional bryophyte records 40. - J. Bryol. 36(3): 224. https://doi.org/10.1179/1743282014Y.0000000115

Papp B., Pantović J., Szurdoki E. \& Sabovljević M. (2014b): Interesting and new species for the bryophyte flora of Serbia - Herzogia 27(1): 221-225. https://doi.org/10.13158/heia.27.1.2014.221

PAPp B., Erzberger P., Ódor P, Hoch Zs., SzÖvéNyi P., SZurdoki E. \& Tóth Z. (2010b): Updated checklist and red list of Hungarian Bryophytes - Studia bot. hung. 41: 31-59.

Papp B., Pantović J., Szurdoki E. \& Sabovljević M. (2016): New bryophyte records for the Republic of Macedonia. - J. Bryol. 38(2): 168-171. https://doi.org/10.1080/03736687.2015.1113628

PAPP B. \& Tsakiri E. (2017): Contribution to the bryophyte flora of the Paiko, Tzena and Pinovo Mts in Greece. - Studia bot. hung. 48(1): 33-49. https://doi.org/10.17110/StudBot.2017.48.1.33

PAPP B. \& SZURDOKI E. (2017): A Káli-medence környéki hegyek mohaflorisztikai feltárása. (Survey on the bryophyte flora of mountains surrounding Káli Basin (Balaton-felvidék Region, Hungary). - Folia Mus. Hist.-Nat. Bakonyiensis, Zirc 34: 15-27.

Papp B. \& SzURdoki E. (2018): Bryophyte flora of the forests of Vétyem and Oltárc Protected Areas (Zala County, W Hungary). - Studia bot. bung. 49(1): 83-96. https://doi.org/10.17110/StudBot.2018.49.1.83

Papp B., Natcheva R. \& Ganeva A. (2011): The bryophyte flora of Northern Mt Strandzha. Phytol. Balcanica 17(1): 21-32.

SABovljević M. \& NATCheVA R. (2006): Checklist of the liverworts and hornworts of SouthEastern Europe. - Phytol. Balcanica 12: 169-180.

Sabovljević M., Alegro A., Sabovljević A., Marka J. \& Vujičić M. (2011): An insight into diversity of the Balkan Peninsula bryophyte flora in the European background. - Revue d'Ecologie (Terre et Vie) 66(4): 399-413.

Sabovljević M., Natcheva R., Dihoru G., Tsakiri E., Dragićević S., Erdă̆ A. \& Papp B. (2008): Check-list of the mosses of SE Europe. - Phytol. Balcanica 14: 207-244.

van Zanten B.O. (2013): Additions to the bryophyte flora of Albania. - Polish Bot. J. 58(1): 287292. https://doi.org/10.2478/pbj-2013-0029

(submitted: 10.11.2018, accepted: 28.11.2018) 


\section{Appendix \\ Complete list of bryophyte records}

The numerals following the species names refer to the collection sites described above.

\section{Liverworts}

Cephaloziella baumgartneri Schiffn. - 11, 15: limestone rock

Cephaloziella divaricata (Sm.) Schiffn. - 1: conglomerate flysch sediment; 3:

limestone rock; 15: at a rivulet; 21: limestone grassland

Clevea spathysii (Lindenb.) Müll. Frib. - 12: limestone rock

Cololejeunea rossettiana (C. Massal.) Schiffn. - 18: limestone rock

Fossombronia caespitiformis (Raddi) De Not. ex Rabenh. - 6: limestone rock; 9: soil among limestone rocks; 15: soil

Frullania dilatata (L.) Dumort. - 1: bark of tree; 3: Fagus bark; 9: bark of Phillyrea and Arbutus unedo; 11: Platanus bark; 15: Quercus bark; 18: bark of Phillyrea

Lejeunea cavifolia (Ehrh.) Lindb. - 3, 18: limestone rock; 15: Platanus bark

Lophocolea heterophylla (Schrad.) Dumort. - 1: soil

Lophocolea minor Nees - 3: limestone rock

Lunularia cruciata (L.) Dumort. ex Lindb. - 6, 9, 12, 15: limestone rock; 8, 10, 16: soil; 18: limestone rock at the spring; 19: soil among limestone rocks; 20: saline grassland; 21 : limestone grassland

Mannia androgyna (L.) A. Evans - 9: limestone rock; 18: soil among limestone rocks

Mesoptychia turbinata (Raddi) L. Söderstr. \& Váňa - 7, 10: limestone rock; 15: at a rivulet

Oxymitra incrassata (Brot.) Sérgio \& Sim-Sim - 23: limestone grassland

Pellia endiviifolia (Dicks.) Dumort. - 10: soil; 11: limestone rock; 22: limestone rock at a spring

Plagiochasma rupestre (J. R. Forst. \& G. Forst.) Steph. - 19: limestone rock; 23: limestone grassland

Plagiochila porelloides (Torr. ex Nees) Lindenb. - 3: limestone rock

Porella platyphylla (L.) Pfeiff. - 3, 18: limestone rock; 11: Platanus bark

Radula complanata (L.) Dumort. - 1: bark of tree; 2: bottom of Fagus; 3: limestone rock and Fagus bark; 7: bark of a shrub; 11, 17: Platanus bark; 15: bark of Ostrya carpinifolia; 18: limestone rock and Platanus bark

Radula lindenbergiana Gottsche ex C. Hartm. - 18: limestone rock 
Reboulia hemisphaerica (L.) Raddi - 2: limestone rock and soil among limestone rocks; 5, 9, 12, 16, 19: limestone rock; 18: soil among limestone rocks; 21: limestone grassland

Riccia ciliata Hoffm. aggr. - 21: limestone grassland (conf. Sérgio, C.)

Riccia sorocarpa Bisch. - 9: limestone rock (conf/det. Sérgio, C.); 13: soil among calcareous conglomerate rocks (conf./det. Sérgio, C.)

Soutbbya nigrella (De Not.) Henriq. - 9, 11, 12: limestone rock; 15: at a rivulet; 16: calcareous conglomerate rock

Southbya tophacea (Spruce) Spruce - 6, 7, 9, 10, 11: limestone rock; 15: at a rivulet

Targionia bypophylla L. - 18: limestone rock; 21: limestone grassland

Targionia lorbeeriana Müll. Frib. - 12, 15: limestone rock; 13, 16: calcareous conglomerate rock; 21, 23: limestone grassland

\section{Mosses}

Abietinella abietina (Hedw.) M. Fleisch.- 2: soil among limestone rocks Alleniella besseri (Lobarz.) S. Olsson, Enroth \& D. Quandt - 3: limestone rock Alleniella complanata (Hedw.) S. Olsson, Enroth \& D. Quandt - 3: limestone rock and Fagus bark; 10: bottom of Platanus tree; 11, 15, 18: Platanus bark; 15: bark of Ostrya carpinifolia

Aloina aloides (Koch ex Schultz) Kindb. - 6, 7, 9: limestone rock; 12: limestone rock and flysch; 15: soil; 24: saline grassland

Aloina ambigua (Bruch \& Schimp.) Limpr. - 9, 11: limestone rock

Amblystegium serpens (Hedw.) Schimp. - 11: limestone rock

Amphidium mougeotii (Schimp.) Schimp. - 3: siliceous rock

Anomodon viticulosus (Hedw.) Hook. \& Taylor - 7, 12, 16: limestone rock; 10, 15, 17, 18: Platanus bark

Barbula unguiculata Hedw. - 2, 4, 6, 7, 9, 11, 19: limestone rock; 15: soil; 18: soil among limestone rocks; 20: saline grassland; 21, 23: limestone grassland; 24: saline grassland

Bartramia aprica Müll. Hal. - 12: limestone rock; 21: limestone grassland Brachytheciastrum velutinum (Hedw.) Ignatov \& Huttunen - 1, 2: conglomerate rock; 3, 15: limestone rock

Brachythecium glareosum (Bruch ex Spruce) Schimp.- 1: conglomerate flysch sediment; 2: soil among limestone rocks

Brachythecium mildeanum (Schimp.) Schimp. - 2: along a rivulet

Brachythecium rivulare Schimp. - 17: limestone rocks at the stream

Brachythecium rutabulum (Hedw.) Schimp. - 2: along a rivulet; 10, 16: soil

Bryoerythrophyllum recurvirostrum (Hedw.) P. C. Chen - 2: limestone rock 
Bryum argenteum Hedw. - 1: conglomerate flysch sediment; 2: conglomerate rock; 7, 9, 12: limestone rock; 15: soil

Bryum canariense Brid. - 18: limestone rock (conf. Schröder, W.)

Bryum dichotomum Hedw. - 1: conglomerate flysch sediment; 2: conglomerate rock; 6: limestone rock (det. Schröder, W.); 23: limestone grassland

Bryum elegans Nees - 2: conglomerate rock

Bryum klinggraeffi Schimp. - 22: soil at a spring

Bryum ruderale Crundw. \& Nyholm - 20: saline grassland

Calliergonella cuspidata (Hedw.) Loeske - 2: along a rivulet

Campyliadelphus chrysophyllus (Brid.) R. S. Chopra - 10, 16: soil

Campylidium calcareum (Crundw. \& Nyholm) Ochyra - 10: bottom of Platanus tree; 15: soil and bottom of Quercus

Campylium protensum (Brid.) Kindb. - 3: in a moist site

Ceratodon purpureus (Hedw.) Brid. - 1: conglomerate flysch sediment; 2: soil among limestone rocks

Cheilothela chloropus (Brid.) Broth. - 16: soil; 21: limestone grassland

Cinclidotus aquaticus (Hedw.) Bruch \& Schimp. - 14: limestone rock in the water; 18, 22: limestone rock at the spring

Cinclidotus fontinaloides (Hedw.) P. Beauv. - 6: limestone rock; 13: calcareous conglomerate rock; 17: limestone rocks at the stream

Cirriphyllum crassinervium (Taylor) Loeske \& M. Fleisch. - 3: in a moist site; 15: limestone rock and Platanus bark; 16: limestone rock; 17: limestone rocks at the stream

Cratoneuron filicinum (Hedw.) Spruce - 2: along a rivulet; 7: limestone rock; 10: soil; 18, 22: limestone rock at the spring

Crossidium squamiferum (Viv.) Jur. - 2: conglomerate rock; 6, 9, 15, 16: limestone rock; 13: calcareous conglomerate rock

Cryphaea beteromalla (Hedw.) D. Mohr - 18: bark of Ligustrum vulgare

Ctenidium molluscum (Hedw.) Mitt. - 3, 6, 9, 15, 16: limestone rock; 10: soil

Dialytrichia mucronata (Brid.) Broth. - 9: limestone rock; 12: limestone rock; bark of Juglans and Platanus; 16: calcareous conglomerate rock and Platanus bark; 17: limestone rocks at the stream and Platanus bark; 18: Platanus bark

Dicranella beteromalla (Hedw.) Schimp. - 21: limestone grassland

Dicranella bowei Renauld \& Cardot - 2: conglomerate rock; 6, 7, 9, 11, 12, 19 : limestone rock; 15: soil; 16: calcareous conglomerate rock; 20: saline grassland; 21: limestone grassland; 24: saline grassland

Dicranella varia (Hedw.) Schimp. - 2: along a rivulet; 10: soil; 11: limestone rock; 15: at a rivulet

Dicranoweisia cirrata (Hedw.) Lindb. - 15: bark of tree 
Dicranum scoparium Hedw. - 1: conglomerate flysch sediment; 2: soil among limestone rocks

Didymodon acutus (Brid.) K. Saito - 1: conglomerate flysch sediment; 2, 4, 7, 9: limestone rock; 13: calcareous conglomerate rock; 15: soil

Didymodon fallax (Hedw.) R. H. Zander - 6, 7, 9: limestone rock; 15: soil at a rivulet and Platanus bark

Didymodon insulanus (De Not.) M. O. Hill - 12: limestone rock; 15: sandstone rock

Didymodon luridus Hornsch. - 2: conglomerate rock (det. Schröder, W.); 6, 9 , 11, 12, 19: limestone rock; 15: soil; 17: limestone rocks at the stream

Didymodon sinuosus (Mitt.) Delogne - 16: limestone rock; 17: at the stream; 18: limestone rock at the spring

Didymodon tophaceus (Brid.) Lisa subsp. tophaceus - 6: limestone rock; 15: at a rivulet

Didymodon tophaceus subsp. sicculus (M. J. Cano, Ros, García-Zam. \& J. Guerra) Kučera - 11: limestone rock; 20: saline grassland

Didymodon vinealis (Brid.) R. H. Zander - 6, 9: limestone rock; 10: soil; 12: limestone rock and flysch; 15: soil; 24: saline grassland

Ditrichum flexicaule (Schwägr.) Hampe - 16: limestone rock

Ditrichum gracile (Mitt.) Kuntze - 16: limestone rock

Ditrichum pusillum (Hedw.) Hampe - 1: conglomerate flysch sediment

Drepanocladus aduncus (Hedw.) Warnst. - 25: in a pond

Drepanocladus polygamus (Schimp.) Hedenäs - 15: at a rivulet

Encalypta rhaptocarpa Schwägr. - 9: limestone rock

Encalypta streptocarpa Hedw. - 2: bottom of Fagus; 16: limestone rock

Encalypta vulgaris Hedw. - 16: limestone rock

Entosthodon mublenbergii (Turner) Fife - 12: limestone rock

Entostbodon pulchellus (H. Philib.) Brugués - 9: limestone rock; 12: flysch

Ephemerum recurvifolium (Dicks.) Boulay - 20: saline grassland; 21: limestone grassland

Eucladium verticillatum (With.) Bruch \& Schimp. - 6, 9, 10, 11, 12: limestone rock; 15: at a rivulet

Eurbynchiastrum pulchellum (Hedw.) Ignatov \& Huttunen - 3, 9: soil among limestone rocks

Exsertotheca crispa (Hedw.) S. Olsson, Enroth \& D. Quandt - 3: limestone rock; 18: base of tree

Fabronia pusilla Raddi - 12: Juglans bark; 15: sandstone rock

Fissidens adianthoides Hedw. - 3: in a moist site 
Fissidens bambergeri Schimp. (F. viridulus var. bambergeri (Schimp.) Waldh.) 1: conglomerate flysch sediment; 6, 7: limestone rock; 16: calcareous conglomerate rock

Fissidens bryoides Hedw. - 4, 9, 10, 18, 19: soil among limestone rocks; 15: soil; 21: limestone grassland

Fissidens crassipes Wilson ex Bruch \& Schimp. - 10: limestone rock

Fissidens curvatus Hornsch. - 3, 9: soil among limestone rocks

Fissidens dubius P. Beauv. - 1: conglomerate flysch sediment; 2, 3, 4, 9, 10, 15, 16: limestone rock

Fissidens taxifolius Hedw. - 1: conglomerate flysch sediment; 2: along a rivulet; 10: soil; 11, 18: limestone rock; 15: at a rivulet

Fissidens viridulus (Sw. ex anon.) Wahlenb. - 6: limestone rock; 15, 16: soil; 18, 19: soil among limestone rocks; 20: saline grassland; 21, 23: limestone grassland

Funaria hygrometrica Hedw. - 6: limestone rock; 23: limestone grassland

Grimmia decipiens (Schultz) Lindb. - 1: conglomerate flysch sediment (rev. Maier, E.)

Grimmia dissimulata E. Maier - 1: conglomerate flysch sediment (conf. Maier, E.); 7, 9: limestone rock (all conf. Maier, E.); 16: limestone rock

Grimmia fuscolutea Hook. - 1: conglomerate flysch sediment (rev. Maier, E.)

Grimmia laevigata (Brid.) Brid. - 1: conglomerate flysch sediment (conf. Maier, E.); 2: conglomerate rock

Grimmia meridionalis (Müll. Hall.) E. Maier - 1: conglomerate flysch sediment (conf. Maier, E.)

Grimmia orbicularis Bruch ex Wilson - 5: limestone rock; 9: limestone rock (conf. Maier, E.)

Grimmia ovalis (Hedw.) Lindb. - 2: conglomerate rock (conf. Maier, E.)

Grimmia pulvinata (Hedw.) Sm. - 1: conglomerate flysch sediment; 2: conglomerate rock (conf. Maier, E.); 6, 16: limestone rock; 9: limestone rock (conf. Maier, E.); 13: calcareous conglomerate rock; 15: limestone and sandstone rocks; 21: limestone grassland

Grimmia tergestina Tomm. ex Bruch \& Schimp. - 2: conglomerate rock (conf. Maier, E.), limestone rock (conf. Maier, E.) and acidic rock; 4, 7, 9: limestone rock (all conf. Maier, E.); 5, 6: limestone rock; 13: calcareous conglomerate rock (conf. Maier, E.); 15: sandstone rock and limestone rock (conf. Maier, E.)

Gymnostomum calcareum Nees \& Hornsch. - 10, 12: limestone rock

Gymnostomum viridulum Brid. - 2, 6, 7, 9, 11, 12: limestone rock; 15: limestone rock and soil at a rivulet

Gyroweisia tenuis (Hedw.) Schimp. - 5, 9, 11, 12: limestone rock; 15: at a rivulet 
Habrodon perpusillus (De Not.) Lindb. - 9: bark of Phillyrea, Carpinus, and Arbutus unedo; 15: bark of tree and Quercus; 16: bark of Fraxinus and Juglans regia; 17: Platanus bark

Homalothecium lutescens (Hedw.) H. Rob.- 2, 3, 7: soil among limestone rocks; 12: flysch; 15: soil and bottom of Ostrya carpinifolia; 16: soil; 18: Platanus bark

Homalothecium sericeum (Hedw.) Schimp. - 2: conglomerate and limestone rocks, bark of Juniperus and bottom of Fagus; 3: limestone rock; 7: bark of a shrub and Quercus; 9: limestone rock and bark of Phillyrea; 10: bottom of Platanus tree; 11, 16, 18: Platanus bark; 15: sandstone rock, bark of Platanus and Quercus; 21: limestone grassland

Hygrobypnum luridum (Hedw.) Jenn. - 3: in a moist site

Hylocomium splendens (Hedw.) Schimp. - 3: soil among limestone rocks

Hypnum cupressiforme Hedw. - 1: conglomerate flysch sediment; 2: soil among limestone rocks; 3, 16: limestone rock; 9: Quercus bark; 10: bottom of Platanus tree; 15: soil

Hypnum cupressiforme Hedw. var. lacunosum Brid. - 1: conglomerate flysch sediment; 2: conglomerate rock; 7, 9: limestone rock

Imbribryum alpinum (Huds. ex With.) N. Pedersen - 1: conglomerate flysch sediment; 15: limestone rock

Imbribryum mildeanum (Jur.) J. R. Spence - 2: conglomerate rock (conf. Schröder, W.); 15: soil (cf. det. Meinunger, L.)

Isothecium alopecuroides (Lam. ex Dubois) Isov. - 3: limestone rock

Isothecium myosuroides Brid. - 18: bark of tree

Leptodictyum riparium (Hedw.) Warnst. - 18: at the spring

Leptodon smithii (Hedw.) F. Weber \& D. Mohr - 7: bark of tree; 9: bark of Phillyrea, Arbutus unedo, Pistacia, and Quercus; 10: bottom of Platanus tree; 15: Quercus bark; 16: bark of Juglans regia; 12, 18: Platanus bark

Leucodon sciuroides (Hedw.) Schwägr. - 1: bark of tree; 2: Carpinus bark; 3: bark of Malus (var. morensis) and limestone rock; 7: bark of tree; 15: Quercus bark

Microeurbynchium pumilum (Wilson) Ignatov \& Vanderp. - 10, 18: soil among limestone rocks

Mnium stellare Hedw. - 3: limestone rock; 15: Platanus bark

Nogopterium gracile (Hedw.) Crosby \& W. R. Buck - 9: limestone rock, bark of Pistacia, Quercus, and Arbutus unedo; 7: bark of a shrub; 12, 16: limestone rock

Orthotrichum affine Schrad. ex Brid. - 3: Fagus bark; 9: bark of Phillyrea and Arbutus unedo; 15: bark of Platanus and Sorbus; 17: Platanus bark

Orthotrichum alpestre Bruch \& Schimp. - 3: Fagus bark 
Orthotrichum anomalum Hedw. - 2: conglomerate and limestone rocks; 4, 7, 9, 16: limestone rock; 15: conglomerate rock; 17: Platanus bark

Orthotrichum cupulatum Hoffm. ex Brid. - 2, 16: limestone rock; 12: limestone rock (conf. Garilleti, R.); 13: calcareous conglomerate rock

Orthotrichum cupulatum Hoffm. ex Brid. var. riparium Huebener - 17: limestone rocks at the stream

Orthotrichum diaphanum Schrad. ex Brid. - 12: Juglans bark; 15: bark of tree and Quercus

Orthotrichum lyellii Hook. \& Taylor - 7: bark of tree; 15: Quercus bark

Orthotrichum pallens Bruch ex Brid. - 3: Fagus bark; 15: bark of tree

Orthotrichum patens Bruch ex Brid. - 15: bark of tree

Orthotrichum philibertii Venturi - 15: Sorbus bark

Orthotrichum rupestre Schleich. ex Schwägr. - 1: bark of tree; 3: limestone rock and Fagus bark; 15: limestone rock

Orthotrichum shawii Wilson - 3: Fagus bark

Orthotrichum speciosum Nees - 2: bark of Juniperus and Fagus; 7: bark of a shrub

Orthotrichum stramineum Hornsch. ex Brid. - 3: Fagus bark

Orthotrichum striatum Hedw. - 3: Fagus bark; 15: Platanus bark

Orthotrichum tenellum Bruch ex Brid. - 15: Sorbus bark (conf. Garilleti, R.); 17:

Platanus bark (conf. Garilleti, R.)

Oxyrrbynchium hians (Hedw.) Loeske - 2: along a rivulet; 4, 6, 11: limestone rock; 10, 15: soil; 22: limestone rock at a spring

Oxyrrhynchium schleicheri (R. Hedw.) Röll - 10: soil

Philonotis caespitosa Jur. - 6: limestone rock

Philonotis capillaris Lindb. - 1: conglomerate flysch sediment; 3: soil among limestone rocks; 6: limestone rock

Philonotis marchica (Hedw.) Brid. - 22: limestone rock at a spring

Plagiomnium affine (Blandow ex Funck) T. J. Kop. - 21: limestone grassland

Plagiomnium undulatum (Hedw.) T. J. Kop. - 10, 16: soil; 15: at a rivulet; 18:

limestone rock and rock at the spring

Plasteurbynchium striatulum (Spruce) M. Fleisch. - 15, 16: limestone rock; 18: bark of tree; 21: limestone grassland

Pogonatum aloides (Hedw.) P. Beauv. - 3: limestone rock

Pogonatum urnigerum (Hedw.) P. Beauv. - 3: siliceous rock

Poblia melanodon (Brid.) A. J. Shaw - 6, 11: limestone rock; 10: soil; 15: at a rivulet

Poblia wablenbergii (F. Weber \& D. Mohr) A. L. Andrews - 7: limestone rock; 15: at a rivulet

Polytrichum juniperinum Hedw. 2: soil among limestone rocks

Pseudoleskeella rupestris (Berggr.) Hedenäs \& L. Söderstr. - 2: decaying wood 
Pseudoscleropodium purum (Hedw.) M. Fleisch. - 1: conglomerate flysch sediment; 3: limestone rock; 15: at a rivulet; 16: soil

Pterigynandrum filiforme Hedw. - 3: limestone rock and Fagus bark; 15: sandstone rock

Ptychostomum capillare (Hedw.) Holyoak \& N. Pedersen - 1: conglomerate flysch sediment; 6, 12: limestone rock; 10: bottom of Platanus tree; 24: saline grassland

Ptychostomum donianum (Grev.) Holyoak \& N. Pedersen - 12: limestone rock; 15: soil (conf. Schröder, W.); 16: soil

Ptychostomum imbricatulum (Müll. Hal.) Holyoak \& N. Pedersen (Bryum caespiticium) - 6, 11: limestone rock

Ptychostomum pseudotriquetrum (Hedw.) J. R. Spence \& H. P. Ramsay - 2: along a rivulet; 9,12 : limestone rock; 10: soil

Ptychostomum rubens (Mitt.) Holyoak \& N. Pedersen - 20: saline grassland

Ptychostomum torquescens (Bruch \& Schimp.) Ros \& Mazimpaka - 6: limestone rock; 23: limestone grassland

Racomitrium canescens (Hedw.) Brid. - 1: conglomerate flysch sediment (conf. Bednarek-Ochyra, H.); 2: conglomerate rock (conf. Bednarek-Ochyra, H.)

Rhynchostegiella curviseta (Brid.) Limpr. - 6: limestone rock; 15: at a rivulet; 17: limestone rocks at the stream; 18: limestone rock

Rhynchostegiella tenella (Dicks.) Limpr. - 9, 12: limestone rock; 18: Platanus bark; 23: limestone grassland

Rhynchostegiella teneriffae (Mont.) Dirkse \& Bouman - 18: limestone rock

Rhynchostegium confertum (Dicks.) Schimp. - 15: soil and limestone rock; 17: limestone rocks at the stream; 18: limestone rock at the spring and bark of Ligustrum vulgare

Rhynchostegium megapolitanum (Blandow ex F. Weber \& D. Mohr) Schimp. - 2, $16,18,19$ : soil among limestone rocks; 21, 23: limestone grassland

Rhynchostegium riparioides (Hedw.) Cardot- 3, 15: at a rivulet; 18, 22: limestone rock at a spring

Rhytidiadelphus triquetrus (Hedw.) Warnst. - 3: limestone rock

Saelania galucescens (Hedw.) Broth. - 2: conglomerate rock

Schistidium apocarpum (Hedw.) Bruch \& Schimp. - 3: siliceous rock

Schistidium atrofuscum (Schimp.) Limpr. - 2: limestone rock

Schistidium brunnescens Limpr. subsp. griseum (Nees \& Hornsch.) H. H. Blom - 2: conglomerate rock (conf. Schröder, W.); 13: calcareous conglomerate rock

Schistidium crassipilum H. H. Blom - 2, 3, 7, 6, 9, 11, 16: limestone rock; 13: calcareous conglomerate rock; 15: limestone and conglomerate rocks; 17 : limestone rocks at the stream 
Schistidium flaccidum (De Not.) Ochyra - 2: acidic rock

Schistidium belveticum (Schkuhr) Deguchi - 1: conglomerate flysch sediment; 2: conglomerate rock; 4, 5: limestone rock

Schistidium papillosum Culm. - 1: conglomerate flysch sediment Sciuro-hypnum populeum (Hedw.) Ignatov \& Huttunen - 3: limestone rock Scleropodium touretii (Brid.) L. F. Koch - 12: flysch; 15: sandstone rock; 16: soil; 21: limestone grassland

Scorpiurium circinatum (Bruch) M. Fleisch. \& Loeske - 4, 6, 7, 9, 12, 15, 19 : limestone rock; 10: soil; 13, 16: calcareous conglomerate rock; 14: on limestone rock in the water; 17: limestone rocks at the stream; 18: limestone rock and Platanus bark; 20: saline grassland; 21, 23: limestone grassland

Scorpiurium sendtneri (Schimp.) M. Fleisch. - 18: Platanus bark

Seligeria pusilla (Hedw.) Bruch \& Schimp. - 12: limestone rock

Streblotrichum commutatum (Jur.) Hilp. - 1: conglomerate flysch sediment

Streblotrichum convolutum (Hedw.) P. Beauv. - 2: limestone rock; 15: soil

Syntrichia laevipila Brid. - 10: Platanus bark; 12: bark of Phillyrea; 15: Quercus bark

Syntrichia montana Nees - 1: conglomerate flysch sediment; 2: conglomerate and limestone rocks; 4, 5, 6, 7, 9, 16: limestone rock; 12 : limestone rock and Juglans bark; 13: calcareous conglomerate rock; 21: limestone grassland

Syntrichia montana Nees var. calva (Durieu \& Sagot ex Bruch \& Schimp.) J. J. Amann - 2: conglomerate and limestone rocks; 5: limestone rock

Syntrichia ruralis (Hedw.) F. Weber \& D. Mohr - 1: conglomerate flysch sediment; 2: conglomerate rock; 3, 7: limestone rock; 15: soil and sandstone rock; 16: soil

Syntrichia virescens (De Not.) Ochyra - 2: bottom of Fagus; 11: limestone rock; 15: bark of tree and Quercus

Thamnobryum alopecurum (Hedw.) Gangulee - 18: limestone rock at the spring Timmiella barbuloides (Brid.) Mönk. - 19: limestone rock; 21: limestone grassland

Tortella fasciculata (Culm.) Culm. - 3, 4: limestone rock

Tortella inclinata (R. Hedw.) Limpr. - 2: conglomerate and limestone rocks; 5: limestone rock

Tortella inflexa (Bruch) Broth. - 12: limestone rock

Tortella nitida (Lindb.) Broth. - 16, 18, 19: limestone rock; 21, 23: limestone grassland

Tortella squarrosa (Brid.) Limpr. - 1: conglomerate flysch sediment; 4, 18: soil among limestone rocks; 7, 9, 12, 15: limestone rock; 16: soil

Tortella tortuosa (Hedw.) Limpr. - 2: conglomerate rock and bottom of Fagus; 3: limestone rock and Fagus bark; 9, 16: limestone rock 
Tortella tortuosa (Hedw.) Limpr. var. fragilifolia (Jur.) Limpr. - 2: conglomerate rock

Tortula inermis (Brid.) Mont. - 2: conglomerate and limestone rocks; 9: limestone rock; 11: Platanus bark; 12: flysch; 15: at a rivulet

Tortula muralis Hedw. var. muralis - 1: conglomerate flysch sediment; 2: conglomerate rock; $6,9,11,12$ : limestone rock; 15: sandstone rock; 21, 23: limestone grassland

Tortula muralis Hedw. var. aestiva Hedw.- 2: bark of Juniperus; 11: limestone rock

Tortula subulata Hedw. - 1: conglomerate flysch sediment; 3: limestone rock; 15: soil

Trichostomum brachydontium Bruch - 1: conglomerate flysch sediment; 9, 16, 18, 19: limestone rock

Trichostomum crispulum Bruch - 5, 6, 7, 9, 10, 12, 16, 18, 19: limestone rock; 13: calcareous conglomerate rock; 15 : soil at a rivulet; 17 : limestone rocks at the stream; 21, 23: limestone grassland

Weissia brachycarpa (Nees \& Hornsch.) Jur. - 21: limestone grassland

Weissia condensa (Voit) Lindb. - 2, 4, 5, 6, 9, 16: soil among limestone rocks; 23: limestone grassland

Weissia controversa Hedw. - 1: conglomerate flysch sediment

Zygodon rupestris Schimp. ex Lorentz - 7: bark of a shrub; 11: limestone rock; 10, 15, 16: Platanus bark 